Kazuhiro Tsukamoto $•$ Ken Haruta $•$ Tadayoshi Shiba Mitsuru Emi

\title{
Isolation and mapping of a polymorphic CA repeat sequence at the human interleukin 6 locus
}

\begin{abstract}
A polymorphic dinucleotide (CA) sequence was isolated from a genomic clone containing the human interleukin 6 (interferon $\beta$-2) gene and was mapped to $7 \mathrm{p} 21$. This polymorphism will be useful in the genetic study of disorders affecting the inflammation process, calcium metabolism, and hematologic malignancies.
\end{abstract}

Key words Interleukin $6 \cdot$ Dinucleotide repeat $\cdot$ Inflammation $\cdot$ Calcium metabolism $\cdot$ Interferon $\beta-2$

\section{Introduction}

Interleukin 6 (IL6) has been also called interferon $\beta-2$ (IFNB2), B-cell differentiation factor (BSF2), hepatocyte stimulatory factor (HSF), or hybridoma growth factor (HGF), according to the biological activities by which this peptide was identified by independent researchers (Zilberstein et al. 1986; Hirano et al. 1986; Sehgal et al. 1987). To understand the relationship between genetic variations at the IL6 locus and disorders affecting the inflammation process, calcium metabolism, and hematologic malignancies, such as rheumatoid arthritis, Paget disease of bone, and multiple myeloma (Kawano et al. 1988; Roodman et al. 1992; Nakamura 1996; Yanase 1997), we isolated and characterized a dinucleotide repeat polymorphism at this locus.

K. Tsukamoto $\cdot$ M. Emi $(\bowtie)$

Department of Molecular Biology, Institute of Gerontology, Nippon Medical School, 1-396 Kosugi-cho, Nakahara-ku, Kawasaki 211, Japan

Tel. +81-44-733-5230; Fax +81-44-733-5192

e-mail:memi@nms.ac.jp

K. Haruta $\cdot$ T. Shiba

Department of Molecular Biology, Faculty of Science, Kitazato

University, Sagamihara, Japan

\section{Source and isolation of $C A$ repeat sequence}

A human genomic clone containing the IL6 gene was identified from a P1-derived artificial chromosome (PAC) library by polymerase chain reaction (PCR) 3-dimensional screening using primer sequences derived from the $3^{\prime}$ portion of the gene. A fragment containing a CA repeat was identified by Southern blotting of PAC DNA digested by HaeIII, Sau3A, or RsaI with a (GT) 20 probe and was subcloned and sequenced. An autoradiogram of the CA repeat sequence is shown in Fig. 1B. PCR primers were designed to flank this new repeat sequence for polymorphism analysis.

PCR primers

Forward (IL6, 6F) 5' TTC TAC ATG ACA GCA GAA CAC 3'

Reverse (IL6, 7R) 5' TCT GTG GGA AAG TAT ATG TGC 3'

\section{PCR conditions}

PCR was performed in a volume of $10 \mu \mathrm{l}$ containing $20 \mathrm{ng}$ genomic DNA, $10 \mathrm{mM}$ Tris $\mathrm{HCl}(\mathrm{pH} 8.4), 50 \mathrm{mM} \mathrm{KCl}$, $1.5 \mathrm{mM} \mathrm{MgCl}, 0.01 \%$ of gelatin, $200 \mu \mathrm{M}$ dNTPs, $2.5 \mathrm{pmol}$ of a $\left[{ }^{32} \mathrm{P}\right]$ end-labeled forward primer and a nonlabeled reverse primer, and 0.25 units of Taq polymerase. Cycle conditions were $94^{\circ} \mathrm{C}$ for $4 \mathrm{~min}$, then 30 cycles of $94^{\circ} \mathrm{C}$ for $30 \mathrm{~s}, 65^{\circ} \mathrm{C}$ for $30 \mathrm{~s}$, and $72^{\circ} \mathrm{C}$ for $30 \mathrm{~s}$, with a final extension step of $5 \mathrm{~min}$ at $72^{\circ} \mathrm{C}$ in a Gene Amp PCR9600 System (Perkin Elmer Cetus, Norwalk, CT, USA) (Nakura et al. 1994). PCR products were electrophoresed in $0.3-\mathrm{mm}$-thick denaturing $6 \%$ polyacrylamide gels containing $36 \%$ formamide and $8 \mathrm{M}$ urea, at $2000 \mathrm{~V}$ for $2-4 \mathrm{~h}$. Gels were transferred to filter papers, dried at $80^{\circ} \mathrm{C}$, and autoradiographed. The sizes of alleles were determined by comparison with the sequencing ladder of a control plasmid. 


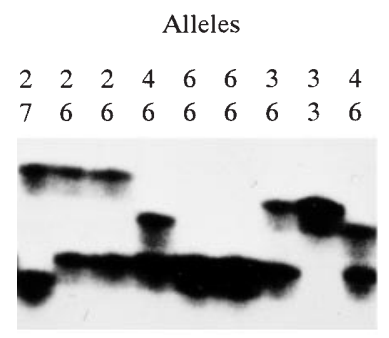

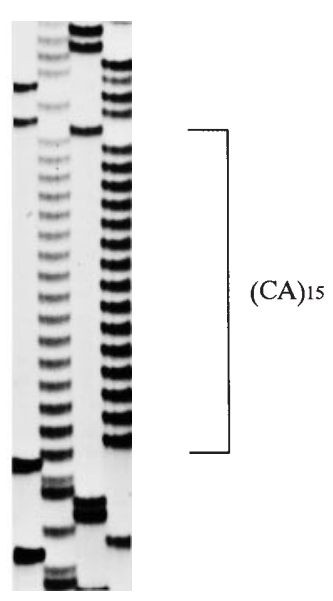

Fig. 1 A Autoradiogram showing a polymorphic CA repeat at the IL6 locus in 9 unrelated individuals. B Nucleotide sequence of the CA repeat and the flanking regions at the IL6 locus

Table 1 Size and frequency of the alleles of the CA repeat polymorphism

\begin{tabular}{lll}
\hline Allele & Size $(\mathrm{bp})$ & Frequency \\
\hline A1 & 134 & 0.05 \\
A2 & 132 & 0.08 \\
A3 & 130 & 0.07 \\
A4 & 128 & 0.03 \\
A5 & 126 & 0.62 \\
A6 & 124 & 0.15 \\
\hline
\end{tabular}

\section{Polymorphism and allele frequency}

Six alleles were detected in 192 chromosomes of unrelated Japanese individuals. A representative autoradiogram of the CA repeat polymorphism is shown in Fig. 1A. The observed heterozygosity was 0.57 . The size and frequency of the six alleles are shown in Table 1.

Mendelian inheritance. Codominant inheritance was observed in two three-generation families.
Chromosomal localization. The human IL6 gene was assigned to human chromosome $7 \mathrm{p} 21$ (Bowcock et al. 1988).

Radiation hybrid mapping. The newly isolated CA repeat at the IL6 locus was mapped to 7p21 using the G3 RH mapping panel of 83 hybrid cell lines of the Stanford Human Genome Center (Boehnke et al. 1991), by linkage to a marker SHGC-37360 with a logarithm of differences (LOD) score of 8.57 .

Acknowledgments This work was supported by research grants for osteoporosis from the Ministry of Health and Welfare of Japan and the Novartis foundation for gerontological research.

\section{References}

Boehnke M, Lang K, Cox DR (1991) Statistical methods for multipoint radiation mapping. Am J Hum Genet 49:1174-1188

Bowcock AM, Kidd JR, Lathrop GM, Daneshvar L, May LT, Ray A, Sehgal PB, Kidd KK, Cavalli LL (1988) The human interferon b-2/ hepatocyte stimulating factor/interleukin 6 gene: DNA polymorphism study and localization to chromosome $7 \mathrm{p} 21$. Genomics 3: 8-16

HiranoT, Yasukawa K, Harada H, Taga T, Watanabe Y, Matsuda T, Kashiwamura S, Nakajima K, Koyama K, Iwamatsu A, Tsunasawa S, Sakiyama F, Matsui H, Takahara Y, Taniguchi T, Kishimoto T (1986) Complementary DNA for a novel human interleukin (BSF-2) that induces B lymphocytes to produce immunoglobulin. Nature 324: 73-76

Kawano M, Hirano T, Matsuda T, Taga T, Horii Y, Iwato K, Asaoku H, Tang B, Tanabe O, Tanaka H, Kuramoto A, Kishimoto T (1988) Autocrine generation and requirement of BSF-2/IL-6 for human multiple myelomas. Nature 332:83-85

Nakura J, Miki T, Ye L, Mitsuda N, Ogihara T, Ohta T, Jinno Y, Niikawa N, Takahashi A, Ishini Y (1994) Six dinucleotide repeat polymorphisms on chromosome 7. Jpn J Hum Genet 39:447449

Nakamura Y (1996) Application of DNA markers to clinical genetics. Jpn J Hum Genet 41:1-14

Roodman GD, Kurihara N, Ohsaki Y, Kukita A, Hosking D, Demulder A, Amith JF, Singer FR (1992) Interleukin 6: a potential autocrine/paracrine factor in Paget's disease of bone. J Clin Invest 89:46-52

Sehgal PB, May LT, Tamm I, Vilcek J (1987) Human beta-2 interferon and B cell differentiation factor BSF-2 are identical. Science 235: $731-732$

Yanase T (1997) Human genetics: past, present, and future. Jpn J Hum Genet 42:265-316

Zilberstein A, Ruggieri R, Korn JH, Revel M (1986) Structure and expression of cDNA and genes for human interferon-beta-2, a distinct species inducible by growth-stimulatory cytokines. EMBO J 5: 2529-2537 